\title{
Development of Decision-Making Software for Patients With Kidney Stones
}

\author{
Martins Krasnovs ${ }^{1}$, Zigurds Markovics ${ }^{2},{ }^{1,2}$ Riga Technical University
}

\begin{abstract}
The paper discusses the development of decisionmaking software for patients with kidney stones. Computerized decision-making about treatment choices for patients with renal stones is step-by-step described in this paper. Medicine is one of the sectors where computerized decision-making is being used more often. One of the key elements of expert systems - building a knowledge base that is based on recommendation fund, known as "Guidelines", is discussed. The paper discusses the most frequently used therapies. Examples of decision trees and production rules are shown.
\end{abstract}

Keywords -Decision making, kidney stones, production rules.

\section{INTRODUCTION}

Nowadays more and more attention is paid to computerized decision-making processes. Different computer programs are developed which allow us to make a decision in several sectors. Such software is designed to facilitate daily work of specialists. Medicine if one of the sectors where computerized decision-making is being used more often. One of the latest software is the computerized decision-making of treatment choices for patients with kidney stones. The existing knowledge of this sector is summarized in the collection of recommendations, known as „Guidelines”, which is useful for the computerized decision-making development process.

Kidney stones can be found in an average of $10-20$ of 10,000 people. The number of patients with kidney stones in the developed countries is gradually increasing. One of the factors why this is happening is the increased protein usage in the diet, inactive lifestyle or lack of fluid intake [3], [12, [14]. In simple cases kidney stones can be dissolved using medications, and stones will pass out by themselves [15]. In more complex situations, it is necessary to perform multiple surgical procedures and patients may need to stay in hospital for several days $[2,13]$.

\section{II.PROPOSED METHOD}

To create a computerized decision-making of treatment choices for patients with kidney stones, guidelines of urolithiasis were used [2]. There are several steps to develop a fully working software, starting with knowledge base creation and finishing with computer program testing.

Step 1) At the beginning all possible diagnoses must be selected for patients with kidney stones. Kidney stones can be located in urinary tract, kidneys and bladder. This paper provides decision-making in cases when the stones are only in kidneys. Regardless where kidney stones are, diagnosis is divided in two parts:

- Uncomplicated kidney stones (without infection);

- Complicated kidney stones (infectious).
In this case there in fact are only two, if kidney stone features (composition, size, and location in the kidney) are not mentioned. Problems begin when it is necessary to choose the optimal therapy, where all stone features and indications, as well as contraindications must be examined and used [2], [3].

Step 2) All possible therapies must be selected. Therapies can be divided in two groups [4]:

- Conservative therapy;

- Surgical therapy.

Conservative therapy holds all types of drug treatment, from simple analgesics to oral chemotherapy. Surgical therapies are [2], [5], [6], [10], [11]:

- Stenting;

- Extracorporeal shock wave lithotripsy (ESWL);

- Ureteroscopy (URS) or Retrograde Intrarenal Surgery (RIRS);

- Percutaneous nephrolithotomy (PNL);

- Laparoscopy;

- Open Surgery.

After that a priority table of treatment choices must be created using composition and size of renal stones. Unfortunately practice shows that renal stone features give no information about the patient, but this kind of information is crucial and must be used for the decision-making [9], [16]. Each therapy gets its own indications that allow to use the selected therapy but there can be one or more contraindications prohibiting the selected therapy. Table 1 gives an example of one of the therapies [2], [3], [8], [9].

Step 3) Since the knowledge base structure is based on decision trees, the information is stored using production rules. Production rules consist of a condition (IF) and action (THEN). Formally it is written: IF (condition) and THEN (action).

The decision tree consists of decision nodes (Indications), chance nodes (contraindications) and end nodes (therapies) [7]. Decision trees must be created for each indication. To make this process easier all indications and contraindications are indexed and later these indexes are used during the programming process. Ureteroscopy indication indexes are [1]:

- Ind6_1 Unsuccessful ESWL therapy;

- Ind6_2 Nephrocalcinosis;

- Ind6_3 Severe obesity;

- Ind6_4 Stones in kidneys and urinary tract at the same time. The contraindications are:

- K_1 Uncontrolled urinary tract infections (UTIs);

- K_4 Intrarenal anatomical abnormalities;

- K_5 Urinary stasis;

- K_14 Bleeding diathesis.

The ureteroscopy decision tree can be seen in Fig. 1. 
TABLE I

INDICATION AND CONTRAINDICATION TABLE FOR URETEROSCOPY AND EXTRACORPOREAL SHOCK WAVE LITHOTRIPSY

\begin{tabular}{|c|c|c|}
\hline Therapy & Indications & Contraindications \\
\hline Ureteroscopy (URS) & $\begin{array}{ll}\text { - } & \text { Unsuccessful ESWL therapy } \\
\text { - } & \text { Nephrocalcinosis } \\
\text { - } & \text { Stonere obesity } \\
\quad \text { can be found in both kidneys and urinary tract }\end{array}$ & $\begin{array}{ll}- & \text { Uncontrolled urinary tract infections (UTIs) } \\
- & \text { Urinary stasis } \\
- & \text { Intrarenal anatomical abnormalities } \\
\text { - } & \text { Bleeding diathesis }\end{array}$ \\
\hline $\begin{array}{l}\text { Extracorporeal shock wave } \\
\text { lithotripsy (ESWL) }\end{array}$ & 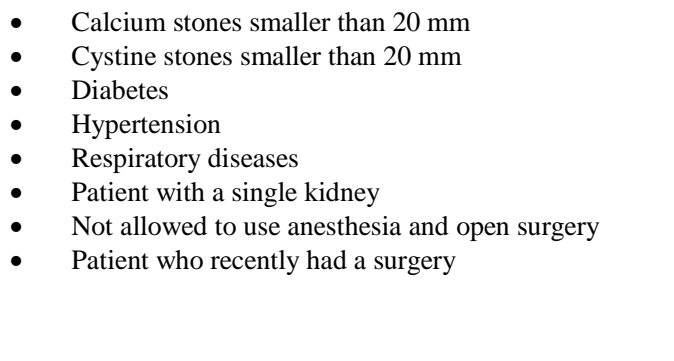 & $\begin{array}{ll}\text { - } & \text { Pregnancy } \\
\text { - } & \text { Severe skeletal malformations } \\
\text { - } & \text { Uncrial aneurysm } \\
\text { - } & \text { Severe obesity } \\
\text { - } & \text { Non-functioning kidney } \\
\text { - } & \text { Urinary stasis } \\
\text { - } & \text { Unolapsed kidney } \\
\text { - } & \text { Intracessul anal ESWL therapy } \\
\end{array}$ \\
\hline Laparoscopy and open surgery & $\begin{array}{ll}\text { - } & \text { Infectious stone burden } \\
\text { - } & \text { Unsuccessful ESWL, PNL and URS therapies } \\
\text { - } & \text { Severe obesity } \\
\text { - } & \text { Non-functioning kidney } \\
\text { - } & \text { Severe skeletal malformations } \\
\text { - } & \text { Arterial aneurysm } \\
\text { - } & \text { Prolapsed kidney }\end{array}$ & - $\quad$ Blood coagulation problems \\
\hline
\end{tabular}

In order not to draw exactly the same four trees, where the only difference is decision nodes (Indications), a decision tree was drawn where all four indications are at the decision node and indexed it with Ind_6.

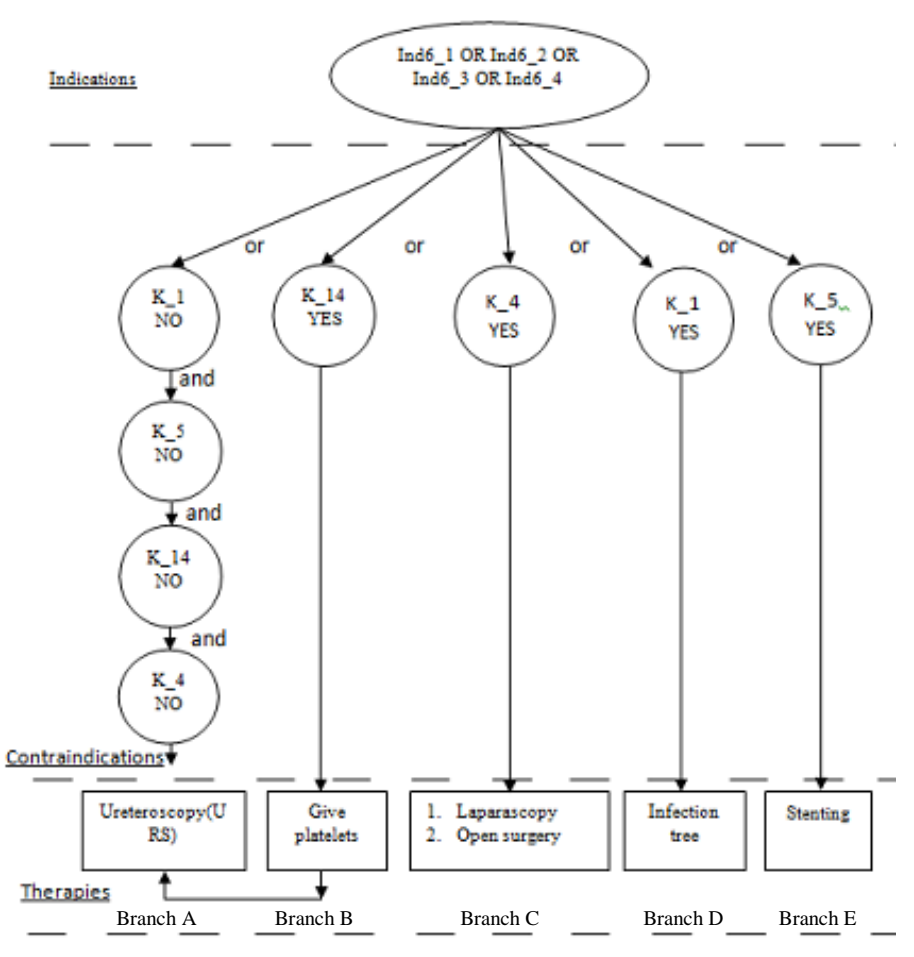

Fig. 1. Example of Ureteroscopy decision tree.

Step 4) The next step is to write the production rules. At the beginning the rules are written for each branch separately and afterwards all possible branch combinations must be described. Note: Not all production rules are shown:
PR 1 (Branch A)

PR 2 (Branch B)

PR 3 (Branch D+E)

PR 4 (Branch C+D+E)

IF there is Ind_6 AND (no K_1) AND (no K_5) AND (no K_14) AND (no K_4) THEN „Ureteroscopy”;

IF there is Ind_6 AND (yes K_14) AND (no K_4) AND (no K_1) AND (no K_5)

THEN „Give Platelets" AND „Ureteroscopy”;

IF there is Ind_6 AND (yes K_1) AND (yes K_5) AND (no K_14) AND (no K_4)

THEN go to "Infection tree";

IF there is Ind_6 AND (yes K_4) AND (yes K_1) AND (yes K_5) AND (no K_14)

THEN go to „Infection tree” AND „Use Laparoscopy or Open Surgery";

PR5 (Branch $\mathrm{B}+\mathrm{C}+\mathrm{D}+\mathrm{E}$ ) IF there is Ind_6 AND (yes K_4) AND (yes K_1) AND (yes K_5) AND (yes K_14)

THEN go to "Infection tree" AND “Give platelets” AND „Use Laparoscopy or Open Surgery";

By the same technique decision trees are made for all indications, followed by all possible production rule combinations between the tree branches.

Extracorporeal shock wave lithotripsy has much more indications and contraindications as it can be seen in Table 1. ESWL indications are [1]:

Ind5_1 Calcium stones smaller than $20 \mathrm{~mm}$;

Ind5_2 Cystine stones smaller than $20 \mathrm{~mm}$; 
Ind5_3 Diabetes;

Ind5_4 Hypertension;

Ind5_5 Respiratory diseases;

Ind5_6 Patient with a single kidney;

Ind5_7 Not allowed to use anesthesia and open surgery;

Ind5_8 Patient who recently has had a surgery.

ESWL contraindication indexes are:

K_1 Uncontrolled urinary tract infections (UTIs);

K_4 Intrarenal anatomical abnormalities;

K_5 Urinary stasis;

K_6 Prolapsed kidney;

K_7 Non-functioning kidney;

K_8 Severe skeletal malformations;

K_10 Arterial aneurysm;

K_11 Severe obesity;

K_12 Unsuccessful ESWL therapy.

ESWL decision tree can be seen in Fig. 2.

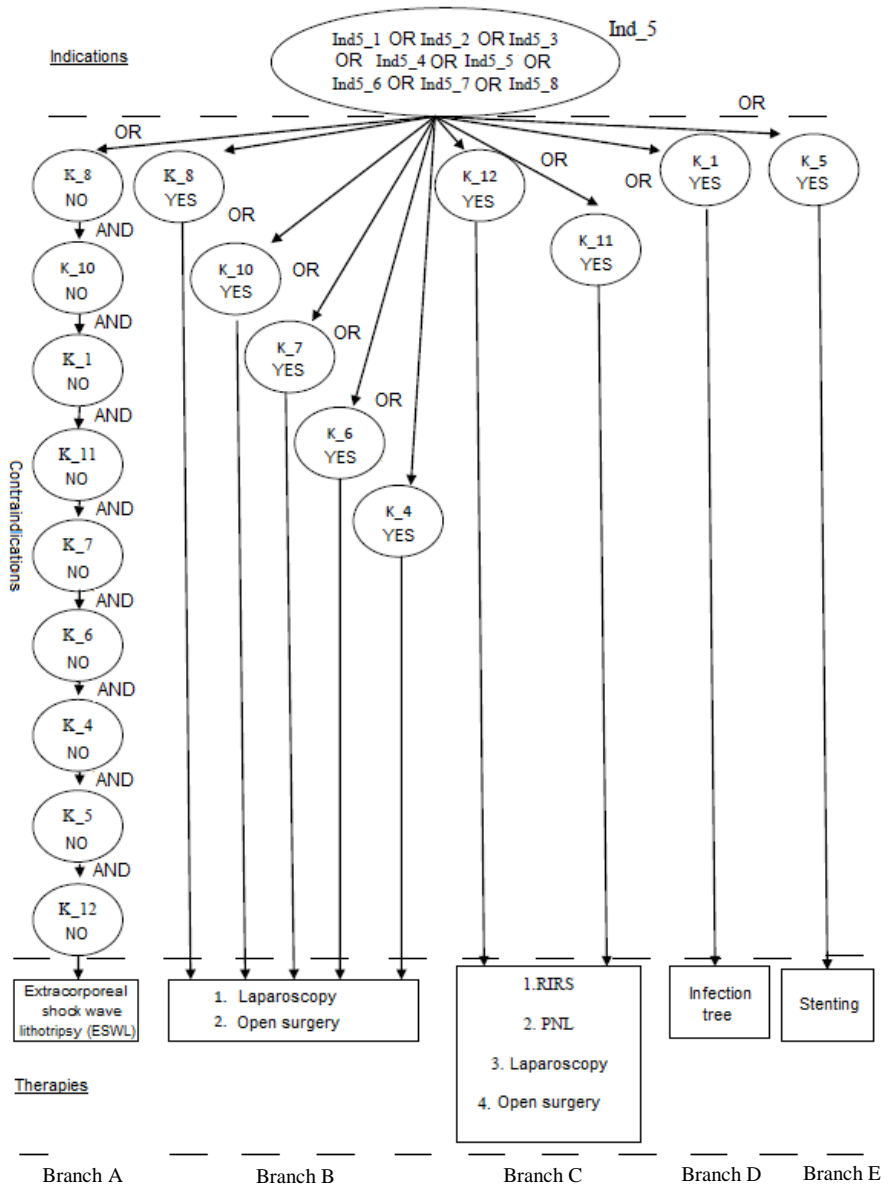

Fig. 2. Decision tree of Extracorporeal shock wave lithotripsy.

Production rules are written for each branch separately and for all possible combinations too. Note: Not all production rules are shown.

PR 1 (Branch A)

IF there is Ind_5 AND (no K_8) AND (no K_10) AND (no K_1) AND (no K_11) AND (no K_7) AND (no K_6) AND (no K_4) AND (no K_5) AND (no K_12) THEN ,ESWL" therapy;
PR 2 (Branch D)

PR 3 (Branch E)

PR 4 (Branch B+D )

PR 5 (Branch D+E)

PR 6 (Branch B+C+D)

PR 7 (Branch B+C+E)

PR 8 (Branch B+C+D+E)

IF there is Ind_5 AND (yes K_1) AND (no K_5) AND (no K_12) OR (no K_11) AND (no K_8) OR (no K_10) OR (no K_7) OR (no K_6) OR (no K_4);

THEN go to „Infection tree”.

IF there is Ind_5 AND (yes K_5) AND (no K_1) AND (no K_11) OR (no K_12) AND (no K_8) OR (no K_10) OR (no K_7) OR (no K_6) OR (no K_4)

THEN ,Stenting”;

IF there is Ind_5 AND (yes K_10) OR (yes K_8) OR (yes K_7) OR (yes K_6) OR (yes K_4) AND (yes K_1) AND (no K_5) AND (no K_12) OR (no K_11)

THEN go to "Infection tree" AND „Use Laparoscopy or Open Surgery";

IF there is Ind_5 AND (yes K_1) AND (yes K_5) AND (no K_8) OR (no K_10) OR (no K_7) OR (no K_6) OR (no K_4) AND (no K_12) OR (no K_11)

THEN go to "Infection tree" AND „ESWL" therapy;

IF there is Ind_5 AND (yes K_8) OR (yes K_10) OR (yes K_7) OR (yes K_6) OR (yes K_4) AND (yes K_12) OR (yes K_11) AND (yes K_1) AND (no K_5)

THEN go to "Infection tree" AND „Use Laparoscopy or Open Surgery";

IF there is Ind 5 AND (yes K_8) OR (yes K_10) OR (yes K_7) OR (yes K_6) OR (yes K_4) AND (yes K_12) OR (yes K_11) AND (yes K_5) AND (no K_1)

THEN "Stenting” AND „Use Laparoscopy or Open Surgery";

IF there is Ind_5 AND (yes K_8) OR (yes K_10) OR (yes K_7) OR (yes K_6) OR (yes K_4) AND (yes K_12) OR (yes K_11) AND (yes K_5) AND (yes K_1)

THEN go to "Infection tree" AND „Use Laparoscopy or Open Surgery".

There is a possibility that the decision must be made by moving from one tree to another. The decision process can be cyclic. Such an example is the production rule 2 (Branch D) from Extracorporeal shock wave lithotripsy tree. It says that the therapy is "Infection tree". If the patient has got the uncontrolled urinary tract infection (UTIs), it will always lead to the infection tree. This tree differs from the others, because 
$2014 / 15$

there is only one contraindication which determines the sequence of therapy. The contraindication is:

$\mathrm{K} \_13$ Situation is life-threatening. Act immediately.

If the decision tree gives more than one therapy, all of them must be performed in the given order.

The infection decision tree can be seen in Fig. 3.

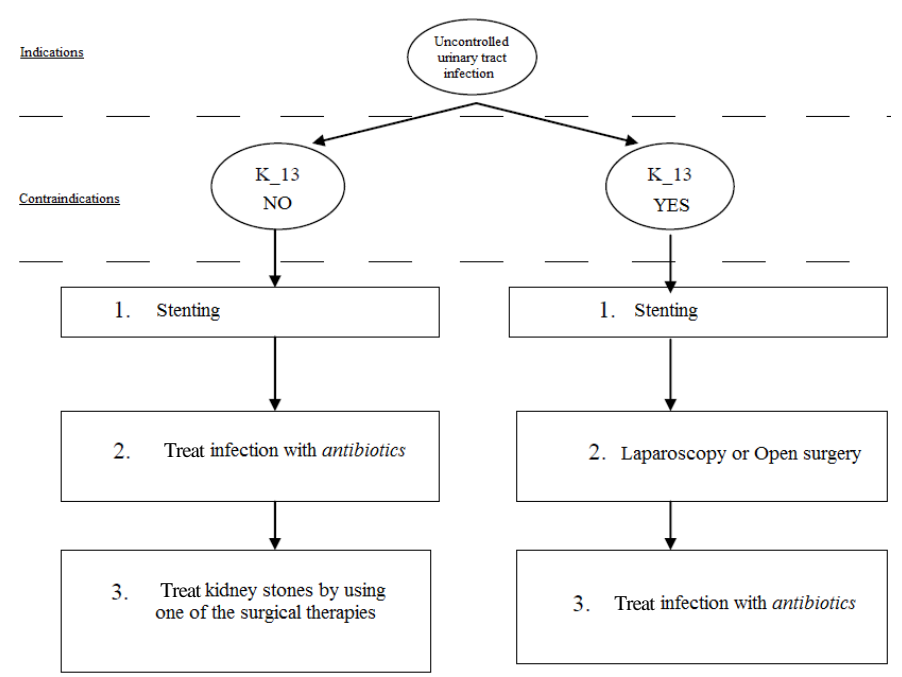

Therapies

Fig. 3. Infection decision tree.

The production rules are:

PR 1 IF there is (UTI's) AND (no K_13)

THEN "Stenting"

AND "Treat infection with antibiotics"

AND "Treat kidney stones by using one of the surgical therapies";

PR 2 IF there is (UTI's) AND (yes K_13)

THEN "Stenting"

AND "use Laparoscopy or Open surgery"

AND "Treat infection with antibiotics".

There is a possibility that the decision can be made by cyclic operations within one tree. Such an example is the Laparoscopy and Open surgery decision tree. Indications and contraindications can be seen in Table I. Indication indexes are:

Ind14_1 Infectious stone burden;

Ind14_2 Unsuccessful ESWL, PNL and URS therapies;

Ind14_3 Intrarenal anatomical abnormalities;

Ind14_4 Severe obesity;

Ind14_5 Non-functioning kidney;

Ind14_6 Severe skeletal malformations;

Ind14_7 Arterial aneurysm;

Ind14_8 Prolapsed kidney.

Contraindication index is :

K_14 Blood coagulation problems.

Laparoscopy and open surgery have exactly the same decision trees because all indications and contraindications are the same. Laparoscopy is less invasive so it is always going to have higher priority than the open surgery. In order not to draw exactly the same eight trees, where the only difference is decision nodes (Indications), a decision tree has been drawn where all eight indications are at the decision node and are indexed with Ind_14. The decision tree can be seen in Fig. 4.

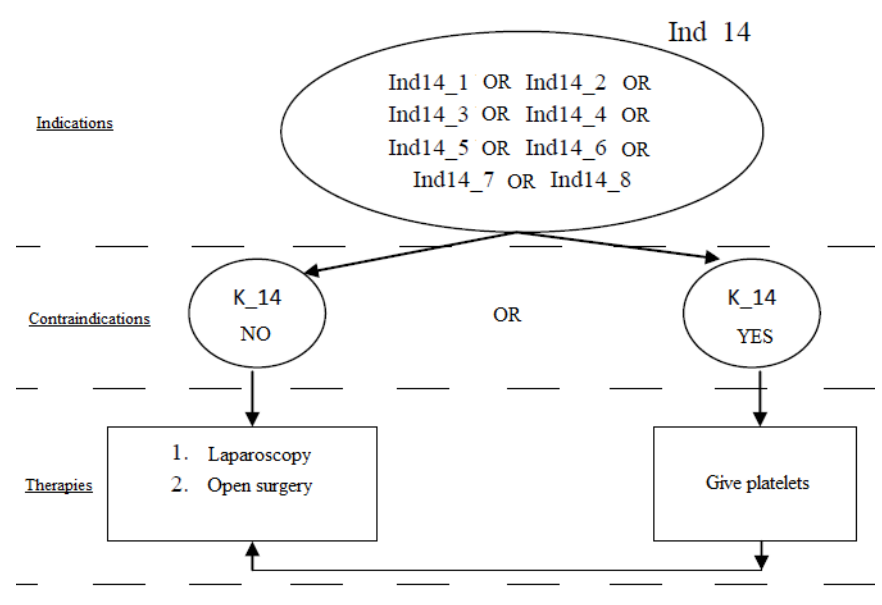

Fig. 4. Laparoscopy and open surgery decision tree.

The production rules are:

PR 1

IF there is Ind_14 AND (no K_14)

PR 2

THEN "Use Laparoscopy or Open surgery";

IF there is Ind_14 AND (yes K_14)

THEN "Give platelets" AND "Use Laparoscopy or Open surgery".

\section{SOFTWARE AND USER INTERFACE}

The software is based on Microsoft Visual Studio, C\# programming language. To save patient data and results, FireBird database is used. To manage and modify database IBExpert was used.

It is possible to save all patient data and test results with all selected indications and contraindications that were used during the test process. The database consists of two tables. The patient table and the test result table.

The patient table consists of 10 fields:

PATIENTID identification number;

FIRSTNAME name of the patient;

LASTNAME surname of the patient;

DATEOFBIRTH date of birth;

SEX gender;

ADDRESS address of the patient;

PHONE telephone number;

EMAIL e-mail of the patient;

FAMILYDOCTOR patient's family doctor;

IDNUMBER personal code of the patient.

This software can be improved with a data sending module, so it is recommended to fill in as many fields as possible. The patient table can be seen in Fig. 5.

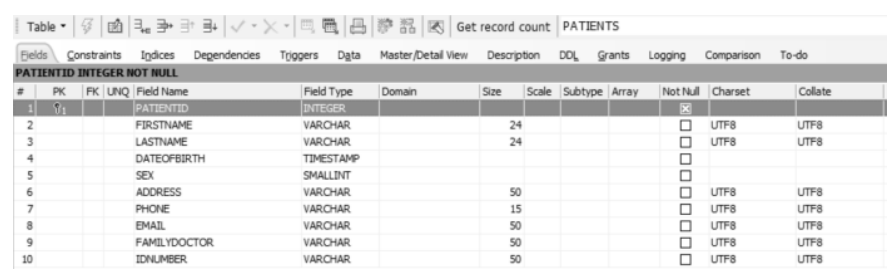

Fig. 5. Patient table. IBExpert view. 
The test result table consists of 6 fields (Fig. 6). All of them are filled automatically during the testing process. The table consists of:

MERIJUMIID identification number of the test;

PATIENDID identifications number of the patient;

DATETIME date and time of the test ;

IDIKACIJAS all indications that are selected;

KONTRINDIKACIJAS all contraindications that are selected as "YES";

TERAPIJA decision on therapy.

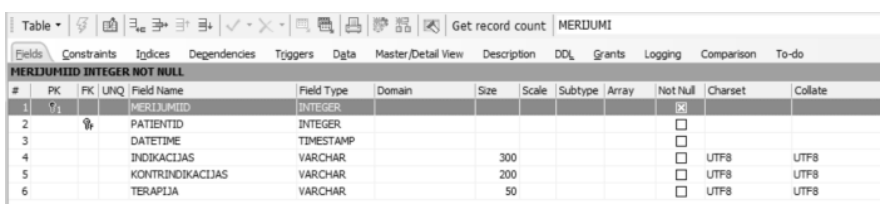

Fig. 6. Test result table. IBExpert view.

\section{USER MANUAL}

The first window of the software consists of two buttons "Pacienti" and "Tests" (Fig. 7). At the very beginning the new patient must be registered in the database. To do that the doctor must press on the button "Pacienti".

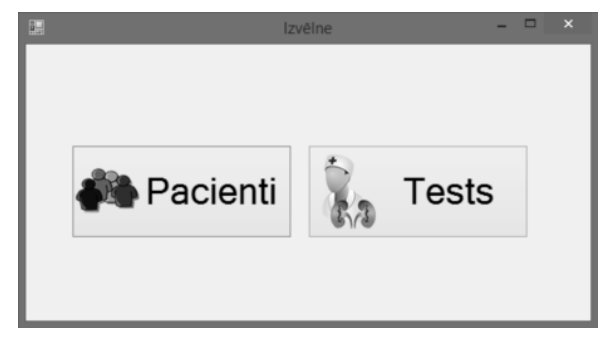

Fig. 7. Main window.

After pressing on "Pacienti" a new form will appear (Fig. 8). By pressing on the button "Pacientu saraksts", the doctor can inspect all patients who have already been registered in the database (Fig. 8). This database consists of one patient. By pressing on the button "Jauns pacients" the doctor can register a new patient by filling in the application form. There are two more buttons at the bottom of this form. "OK" will save all data and close this form and return to the main window. "Atcelt" will discard all changes and close active form and return to the main window (Fig. 8).

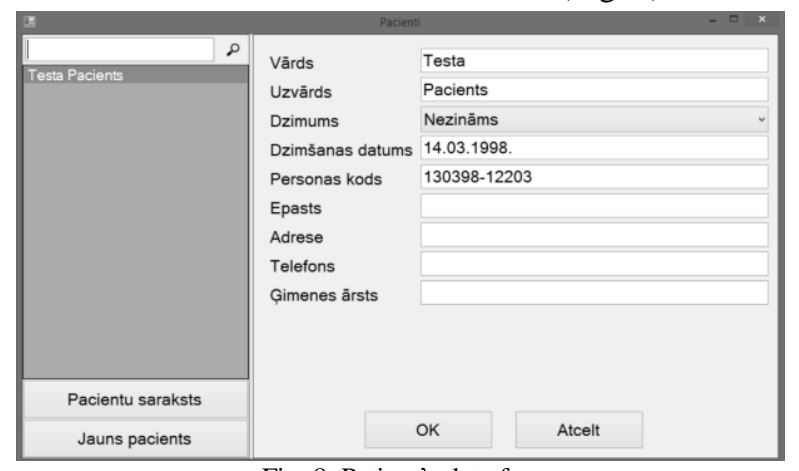

Fig. 8. Patient's data form.
After returning to the main window (Fig. 7) and pressing on the button "Tests", a new form will open where the selected patient's history of test results will be shown. As it can be seen in Fig. 9 the patient "Testa Pacients" has got no tests completed yet and all fields are empty. The software has been developed so that the doctor can come back and check the test results any time. If there is at least one test completed for the selected patient, under the label "Veiktie testi", all tests will be sorted by date and time, and by pressing on one of them the test results will appear under the label "Testa rezultāti". It is really useful because the doctor can compare older results with the new ones. The button "Jauns tests..." will start a new test, but "Aizvērt" will close this form and return to the main window (Fig. 9).

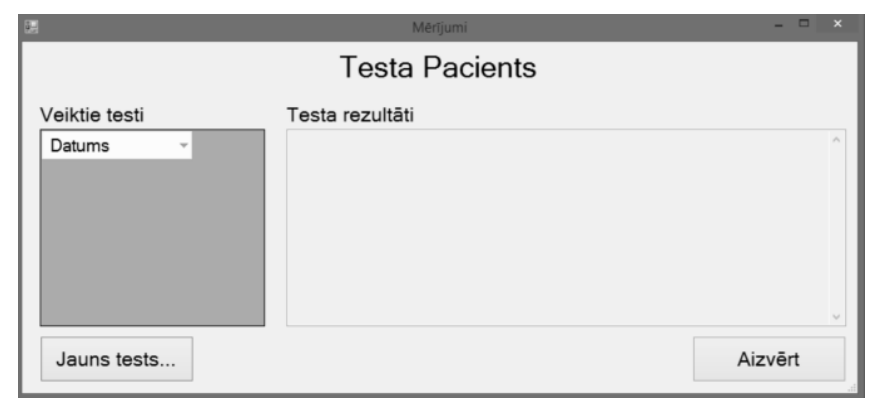

Fig. 9. Selected patient's test results form.

To start a new test the doctor must press on the button "Jauns tests...". A new form will open where the doctor must check all patient's identified features that have been diagnosed. When it is done the doctor can press on the button "Tālāk" to go further or "Atcelt" to cancel all and to close the test form (Fig. 10).

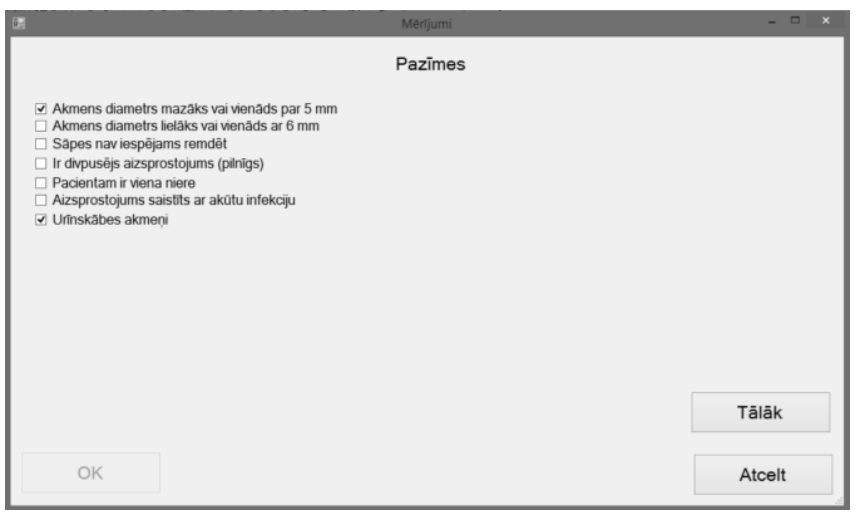

Fig. 10. Patient's features form.

When the doctor presses on "Tālāk", the software will make a decision whether it is a treatment with medication or surgical therapies are needed. In case the patient must be treated by the surgical method, a new form will open where the doctor must check all diagnosed indications (Fig. 11). To go further the doctor must press on the button "Tālāk" or "Atcelt" to discard changes and close this form. 


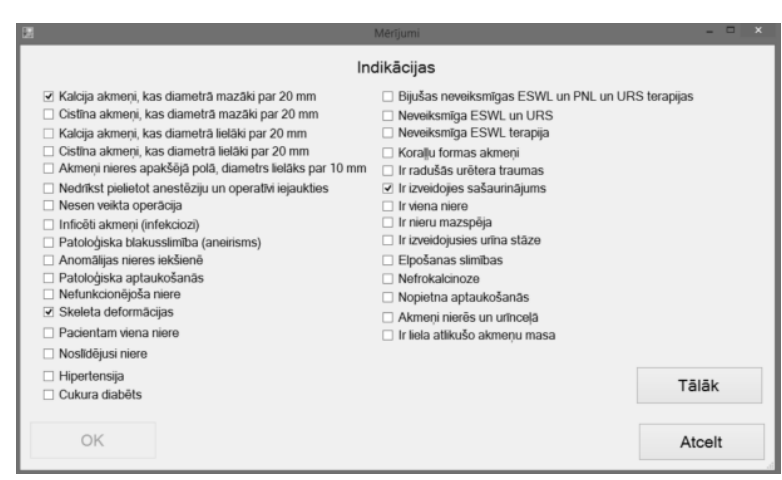

Fig. 11. Indications form.

When all diagnosed indications are checked, the doctor must press on the button "Tālāk". A new form will open, where the doctor must answer all questions from top to bottom. By default all answers are set to "NO", because it is the best possible situation when the patient has got no contraindications at all (Fig. 12). When the doctor has answered all questions, the program is ready to make the decision about the treatment which can be obtained by pressing on the button "Slēdziens".

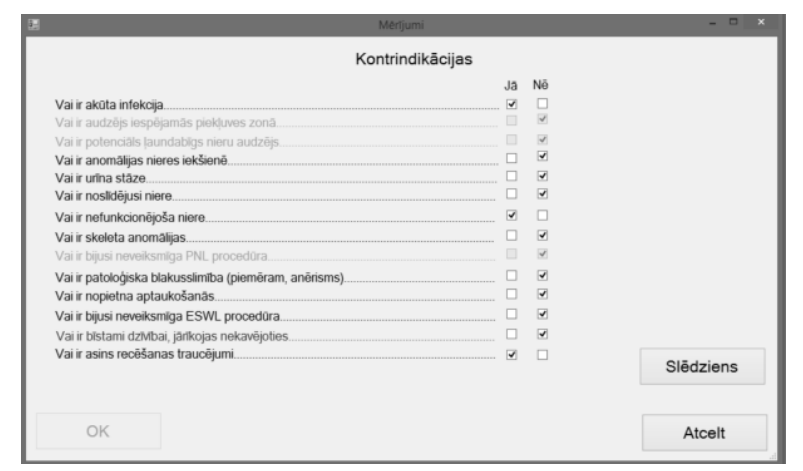

Fig. 12. Contraindications form.

The Decision about the therapy is given in a new form. All selected indications and contraindications are shown too. The doctor can compare his opinion to the one given by the software. The decision form can be seen in Fig. 13.

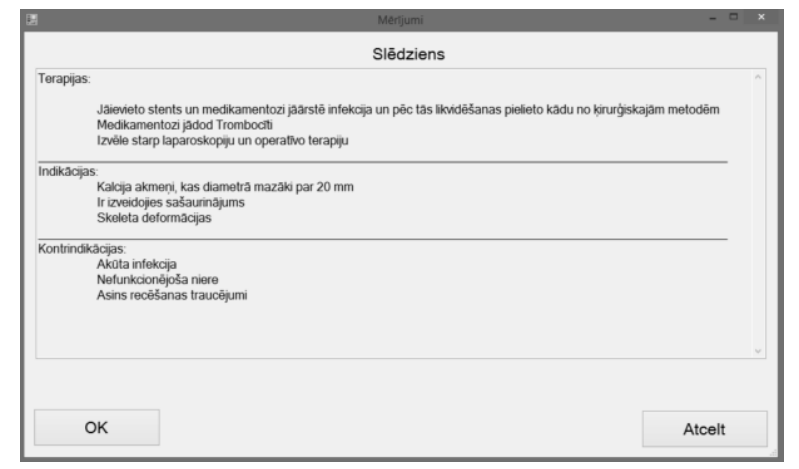

Fig. 13. Decision form.

If the doctor presses button "OK" in the decision form, the test results will be saved in the database and the active form will be closed. If the doctor presses on "Atcelt", the test results will not be saved and the active window will be closed. Now it is possible to check the history of the selected patient's test results because they are saved in the database. The selected patient's test results can be seen in Fig. 14.

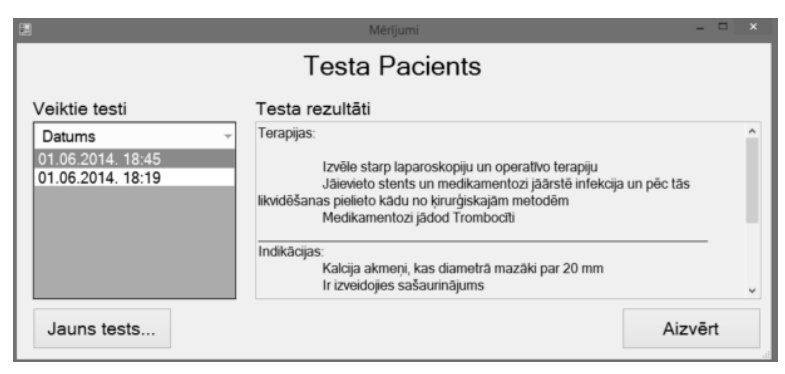

Fig. 14. Test results for the selected patient.

\section{V.RESULT AND CONCLUSION}

The proposed system allows to perform a quick and efficient testing. It is very flexible and supports different hardware. The software was tested by using real life cases. The attending physician completed this test in real life situations and compared the given decision of therapy with his own decision. The given software was accepted as fully working. There are no fundamental mistakes in the production rule logics because they were confirmed by certified urologist and were signed and stamped.

To create a computerized decision-making by using decision trees and production rules, one of the main tasks was to create synthesis of these two elements. One of the most important stages was knowledge formalization and structuring. Extensive knowledge of the disease development and the patient is needed to choose the optimal therapy. A fully working computer program has been developed and the attending physician can use and test it in practice.

\section{REFERENCES}

[1] I. Markoviča, Z. Markovičs, E. Prancāne, "Knowledge Structuring and Decision Making Methodology for Therapy Selection," Scientific Journal of Riga Technical University, Computer Science, vol. 13, Riga, Latvia, 2012, pp. 15-21.

[2] H-G. Tiselius, P. Alken, C. Buck, "Guidelines on Urolithiasis," European Association of Urology, p. 128, 2008.

[3] A. Pētersons, E. Vēverbrants, I. Lazovskis, "Kā atklāt un ārstêt nierakmeņu slimības," A. Pētersona author edition, Latvia, 1998, pp. 374-381.

[4] AHRQ (Agency for HealthCare Research and Quality), Guidelines on urolithiasis, Mar. 2008, [Online], [Accessed on: April 4, 2014]. Available: http://www.guideline.gov/content.aspx?id=45324\&search=Transplant+o f+kidney+

[5] A. M. Davidson, J. S. Cameron, J.-P. Grunfeld, eds., "Oxford Textbook of Clinical Nephrology," Oxford: University Press, 2005, vol. 3, pp. $1243-1254$.

[6] AU. Wing-Hang, "Retrograde Intrarenal Surgery (RIRS): Ureterorenoscopic Lithotripsy for Renal Stones," Medical Bulletin, 2009 , vol. 14 , no. 10 , pp. $23-27$.

[7] L. Novickis, T. Rikure, "Intelektuālo lietišḳo datorsistēmu uzbūves metodes," Riga: Riga Technical University, 2007.

[8] E. M. Worcester, F. L. Coe, "Calcium kidney stones," N. Engl. J. Med., 2010, pp. 363:954-963. http://dx.doi.org/10.1056/NEJMcp1001011

[9] A. Srisubat, S. Potisat, B. Lojanapiwat, V. Setthawong, M. Laopaiboon, "Extracorporeal shock wave lithotripsy (ESWL) versus percutaneous nephrolithotomy (PCNL) or retrograde intrarenal surgery (RIS) for kidney stones," Cochrane Database Syst Rev., Oct. 7, 2009 no. 4. http://dx.doi.org/10.1002/14651858.CD007044.pub2

[10] P. Shen, M. Jiang, J. Yang et al. "Use of ureteral stent in extracorporeal shock wave lithotripsy for upper urinary calculi: a systematic review and meta-analysis," J Urol, 2011, vol. 186, no. 4, pp.1328-1335. http://dx.doi.org/10.1016/j.juro.2011.05.073 
[11] R. D. Monk, D. A. Bushinsky, "Kidney Stones," Kronenberg HM, Melmed S, Polonsky KS, Larsen PR, eds. Williams Textbook of Endocrinology, 2011, vol. 12, Philadelphia, Pa: Saunders Elsevier, ch. 30.

[12] T. Meschi, "Lifestyle recommendations to reduce the risk of kidney stones," Urol Clin North Am, 2011, vol. 38, no. 3, pp. 313-320. http://dx.doi.org/10.1016/j.ucl.2011.04.002

[13] B. R. Matlaga, J. P. Jansen, L. M. Meckley, T. W. Byrne, J. E. Lingeman, "Treatment of ureteral and renal stones: a systematic review and meta-analysis of randomized controlled trials." J Urol, 2012, vol. 188, no. 1, pp. 130-137. http://dx.doi.org/10.1016/j.juro.2012.02.2569

[14] L. Frassetto, "Treatment and prevention of kidney stones: an update," Am. Fam. Physician, 2011, vol. 84, no. 11, pp. 1234-1242.

[15] B. H. Eisner, "Pharmacologic treatment of kidney stone disease," Urol. Clin. North Am., 2013, vol. 40, no. 1, pp. 21-30. http://dx.doi.org/10.1016/j.ucl.2012.09.013

[16] C. Christian, B. Thorsten, "The preferred treatment for upper tract stones is extracorporeal shock wave lithotripsy (ESWL) or ureteroscopic pro ESWL," Urology, 2009, vol. 74, no. 2, pp. 259-262. http://dx.doi.org/10.1016/j.urology.2008.08.522
Martins Krasnovs studied at the Faculty of Computer Science and Information Technology and received his Master degree in Computer Science from Riga Technical University in 2014. Currently he is a PhD student with the Department of Automation and Computer Engineering, Faculty of Computer Science and Information Technology, Riga Technical University. Work experience: Presently he is a programmer-system analyst at TENAX Ltd. and a research assistant with the Faculty of Computer Science and Information Technology, Riga Technical University.

Address: Meza Str. 1/3, Riga LV-1048, Latvia.

E-mail: martins.krasnovs@rtu.lv

Zigurds Markovics, Dr. habil. sc. ing., Professor (since 1993) with the Institute of Computer Control, Automation and Computer Engineering, Faculty of Computer Science and Information Technology, Riga Technical University.

He is the author of 148 scientific publications and 3 monographs.

His research interests are: computer control systems, artificial intelligence systems, robotics.

He is a Member of Latvian Association of Professors and of Latvian Association of Scientists.

Address: Meza Str. 1/4, Riga, LV-1007, Latvia.

E-mail: Zigurds.Markovics@rtu.lv

\section{Mārtiṇš. Krasnovs, Zigurds Markovičs. Lēmuma pieṇemšanas programmatūras izstrāde nierakmeṇu slimniekiem}

Darba mērḳis ir datorsistēmas izveide, kas ir spējīga pieņemt lēmumu par terapijas izvēli nierakmeņu slimniekam.

Lai datorizētu lemšanas procesu, nepieciešams veikt vairākus uzdevumus. Terapijas izvēlei nepieciešamas plašas zināšanas gan par slimības attīstību, gan par pašu pacientu. Šajā nozarē eksistējošās zināšanas ir koncentrētas rekomendāciju krājumā, ko sauc par „Vadlīnijām”, kas ir noderīgas lēmumu pienemšanas dator realizācijai. Līdz ar to viens no uzdevumiem ir izveidot terapijas izvēles datorsistēmu uz vadlīnijās apkopotās zināšanu bāzes. Šāda veida zināšanas var strukturizēt, izmantojot lemšanas kokus, kurus var aprakstît, izmantojot kādu no zināšanu atspoguḷošanas shēmām: produkciju likumi, freimu struktūras, semantiskie tīkli u.c. Šajā darbā produkciju likumi ir izvēlēti par instrumentu lemšanas koku aprakstī̌šāā.

Terapijas tiek izskatītas tikai akmeniem, kas atrodas nierēs. Pēc kịmiskā sastāva ir iespējams uzstādīt medikamentozu terapiju, kura sīkāk šajā darbā netiek pētīta. Programmatūra ir tendēta uz ḳirurğiskās terapijas izvēli, kur katra metode ir izpētita. Katrai metodei ir indikācijas un kontrindikācijas, kas ir galvenais terapijas izvēelè.

Мартиньш Краснов, Зигурдс Маркович. Разработка приложения для принятия решений при почечнокаменных болезнях

Цель работы - разработать приложение, способное принять решение о выборе терапии для больного почечнокаменной болезнью. Чтобыкомпьютеризировать процесс принятия решений, необходимо выполнить несколько заданий. Для выбора вида терапии необходима информация и о развитии болезни, и о самом пациенте. В данной отрасли знания обобщены в сборнике рекомендаций, называемом «Руководством», и именно оно и пригодно для реализации системы принятия решений. Поэтому одна из задач - создать базу знаний, необходимую компьютерной системе. Таким образом знания можно структуризировать, используя деревья принятия решений, которые можно описать, используя одну из схем отображения и хранения данных: продукционные законы, фреймовые структуры, семантические сети итд. В этой работе как инструмент для дерева принятия решений были выбраны продукционные законы.

Виды терапии рассматриваются лишь для камней, находящихся в почках. По химическому составу возможно установить медикаментозную терапию, которая более подробно в этой работе не будет рассмотрена. Компьютерная система в основном предлагает хирургическое вмешательство, где каждый из предоставленных методов тщательно исследован и у каждого метода есть свои собственные индикации и контриндикации, являющиеся ключом в выборе вида терапии. 